\title{
Studi Analisis Pelaksanaan Asesmen terhadap Perkembangan Anak Usia Dini di KB X Pangandaran
}

\author{
Dita Suci Fatmawati* \\ Prodi Pendidikan Guru PAUD, Fakultas Tarbiyah dan Keguruan, \\ Universitas Islam Bandung, Indonesia. \\ *ditasucifatmawati@gmail.com
}

\begin{abstract}
Assessment in early childhood education is an important activity carried out in obtaining, collecting, and analyzing data on early childhood development (religious and moral values, cognitive, physical-motor, language, social-emotional, and art). Assessment or assessment can determine the success of educational institutions that are input for the Institution, for teachers, parents and the community. Through assessment of a PAUD Institution can improve the educational programs and services provided to students. The purpose of the study is to describe how the results of the analysis of the implementation of early childhood development assessments. This study also highlights the factors that affect the implementation of assessments, namely in KB X Pangandaran. The research method used is a descriptive method with a qualitative approach. The data collection techniques used are observation, interview, and documentation. The subjects of the study were the principal and teacher. The analysis used is data collection, data reduction, data presentation, conclusion and verification of data. The results of the study describe assessments on early childhood development including the preparation of assessment programs, instruments used in assessing, principles held by teachers, implementation / recording time, documenting assessment results, data processing, reporting to parents and principals, assessment follow-up, supporting factors and obstacles in the implementation of assessments. The implication of research is that it can be an input or reference material for principals and teachers in order to develop an assessment of early childhood development in KB X Pangandaran.
\end{abstract}

Keywords: Assessment, Development, Early Childhood.

Abstrak. Asesmen dalam pendidikan anak usia dini merupakan kegiatan penting dilakukan dalam memperoleh, mengumpulkan, dan menganalisis data tentang perkembangan anak usia dini (nilai agama dan moral, kognitif, fisik-motorik, bahasa, sosial-emosional, dan seni). Asesmen atau penilaian dapat menentukan keberhasilan Lembaga pendidikan yaitu menjadi masukan bagi Lembaga, bagi guru, para orang tua dan masyarakat. Melalui asesmen sebuah Lembaga PAUD dapat memperbaiki program pendidikan dan layanan yang diberikan kepada anak didik. Tujuan penelitian untuk mendeskripsikan bagaimana hasil analisis terhadap pelaksanaan asesmen perkembangan anak usia dini. penelitian ini juga menyoroti faktor-faktor yang memperngaruhi pelaksanaan asesmen yaitu di KB X Pangandaran. Metode penelitian yang digunakan adalah metode deskriptif dengan pendekatan kualitatif. Teknik pengumpulan data yang digunakan adalah observasi, wawancara, dan dokumentasi. Subjek penelitian adalah kepala sekolah dan guru. Analisis yang digunakan adalah pengumpulan data, reduksi data, penyajian data, kesimpulan dan verifikasi data. Hasil penelitian menggambarkan asesmen terhadap perkembangan anak usia dini meliputi penyusunan program asesmen, instrument yang digunakan dalam menilai, prinsip-prinsip yang dipegang guru, waktu pelaksanaan/pencatatan, pendokumentasian hasil asesmen, pengolahan data, pelaporan kepada orang tua dan kepala sekolah, tindak lanjut asesmen, faktor pendukung dan penghambat dalam pelaksanaan asesmen. Implikasi penelitian adalah dapat menjadi bahan masukan atau rujukan bagi kepala sekolah dan guru-guru dalam rangka mengembangkan penilaian terhadap perkembangan anak usia dini di $\mathrm{KB} X$ Pangandaran.

Kata Kunci: Asesmen, perkembangan, Anak Usia Dini. 


\section{A. Pendahuluan}

Asesmen terhadap perkembangan anak usia dini merupakan kegiatan yang penting dilakukan dalam memperoleh, mengumpulan, serta menganalisis data mengenai perkembangan anak usia dini (nilai agama dan moral, fisik-motorik, kognitif, bahasa, sosial-emosional, dan seni) (1). Dalam kurikulum 2013 PAUD, asesmen atau penilaian dilakukan dengan menggunakan penilian otentik, dimana penilaian dilaksanakan secara kontinu yang bertujuan untuk memperoleh data mengenai perkembangan anak, pada saat kegiatan berlangsung atau melalui hasil karya anak. Selain itu salah satu prinsip asesmen pada anak usia dini adalah bersifat objektif dimana asesmen dilaksanakan terhadap semua aspek perkembangan anak denga napa adanya. Untuk mendapatkan informasi atau data mengenai perkembangan anak tersebut, diperlukan teknik pengumpulan data yang tepat sesuai dengan karakteristik anak usia dini yaitu observasi, percakapan, penugasan, unjuk kerja, hasill karya, portofolio, dan catatan anekdot.

Menurut Arumdari dan Putri (2) menyatakan bahwa "pelaksanaan asesmen terhadap perkembangan anak usia dini dilaksanakan untuk mengetahui bagaimana perkembangan anak berlangsung, apakah sudah sesuai dengan seharusnya atau mengalami hambatan/ pada perkembangan anak tersebut ". Menurut wortham, dkk (3) menyatakan bahwa "salah satu cara yang digunakan guru untuk membekali anak dengan pembinaan PAUD dan PAUD berkualitas adalah melalui asesmen PAUD yang efektif". Menurut maryani (4) menyatakan bahwa "salah satu faktor penting pada pelaksanaan asesmen atau penilaian terhadap perkembangan anak usia dini adalah menentukan kapan dan bagaimana mereka harus diikuti. Selain itu, pelaksanaan asesmen dan pelaporan perkembangan anak usia dini, dilaksanakan oleh guru mulai dari anak tiba di sekolah, sampai anak pulang ke rumah".

Dengan adanya asemen terhadap perkembangan anak usia dini, guru dan orang tua dapat mengetahui permasalahan dan kemajuan dari perkembangan anak. Selain itu, hasil akhir asesmen dapat dipakai atau digunakan sebagai bahan pijakan untuk peningkatan dan penggarapan pembelajaran pada semester selanjutnya (5).

Berdasarkan hal tersebut, pendidik anak usia dini ditantang untuk melaksanakan asesmen terhadap perkembangan anak usia dini menggunakan strategi yang tepat untuk perkembangan anak yang sedang berlangsung (6). Selain itu, pendidik juga harus mampu melaksanakannya sesuai dengan instrumen, metode, dan teknik yang tepat. (7) karena ketidaklengkapan pencatatan perkembangan anak berdampak pada pelaporan perkembangan yang tidak utuh dan holistik.

Berdasarkan latar belakang yang telah diuraikan, maka perumusan masalah dalam penelitian ini sebagai berikut "Bagaimana analisis pelaksanaan asesmen terhadap perkembangan anak usia dini di KB X Pangandaran dan apa yang menjadi faktor pendung dan penghambat KB Qalbun Syakir Pangandaran dalam melaksanakan asesmen terhadap perkembangan anak usia dini". selanjutnya, tujuan dalam penelitian ini diuraikan dalam pokokpokok sebagai berikut.

Untuk mendeskripsikan hasil analisis pelaksanaan asesmen terhadap perkembangan anak usia dini di KB X Pangandaran.

Untuk mendeskripsikan faktor pendukung dan penghambat KB X Pangandaran dalam melaksanakan asesmen terhadap perkembangan anak usia dini.

\section{B. Metodologi Penelitian}

Penelitian ini menggunakan metode deskriptif dengan pendekatan kualitatif. Dilakukan di KB X Pangandaran pada bulan November sampai Desember 2021. Subjek penelitian Kepala Sekolah dan Guru, objek penelitian pelaksanaan asesmen terhadap perkembangan anak usia dini.

Teknik pengumpulan data yang digunakan adalah observasi, wawancara dan dokumentasi. Adapun teknik analisis data yang digunakan dalam penelitian ini adalah pengumpulan data, reduksi data, penyajian data, kesimpulan dan verifikasi data.

\section{Hasil Penelitian dan Pembahasan}




\section{Analisis Pelaksanaan Asesmen terhadap Perkembangan Anak Usia Dini di KB X Pangandaran}

Asesmen terhadap perkembangan anak usia dini merupakan kegiatan yang penting dilakukan dalam memperoleh, mengumpulan dan menganalisis data mengenai perkembangan anak usia dini (nilai agama dan moral, kognitif, fisik-motorik, bahasa, sosial-emosional dan seni). Pelaksanaan asesmen terhadap perkembangan anak usia dini dilakukan mulai dari perencanaan/penyusunan program asesmen, pengumpulan data, pelaksanaan/pencatatan, pendokumentasian, pengolahan data, pelaporan, dan follouw up atau tindak lanjut dari asesmen itu sendiri.

Penyusunan asesmen terhadap perkembangan anak usia dini di KB X Pangandaran dilakukan berdasarkan hasil evaluasi asesmen terhadap perkembangan anak usia dini pada program pembelajaran sebelumnya, kemudian dibuat dan dilakukan program pembelajaran yang akan digunakan pada Program Pembelajaran Tahunan (PROTAH), Program Pembelajaran Semester (PROSEM), Rencana Pelaksanaan Pembelajaran Mingguan (RPPM), dan Rencana Pelaksanaan Pembelajaran Harian (RPPH). Penyusunan ini dilakukan dengan menyesuaikan tingkat perkembangan anak, yaitu dengan melibatkan semua aspek perkembangan anak diantara: nilai agama dan moral, bahasa, kognitif, fisik-motorik, sosial-emosional, dan perkembangan seni. Penyusunan program asesmen terhadap perkembangan anak usia dini di KB X Pangandaran melibatkan pengelola/kepala sekolah dan semua guru kelompok (kelompok A dan Kelompok B), dilakukan pada saat akan ajaran baru secara bersama-sama di satu tempat (misalnya dilakukan di KB X Pangandaran). Dengan demikian Penyusunan program asesmen terhadap perkembangan anak usia dini di KB X sudah sesuai dengan yang seharusnya dimana penyusunan program asesmen terhadap perkembangan anak usia dini tidak hanya dilakukan oleh guru atau kepala sekolah saja namun guru dan kepala sekolah terlibat dalam penyusunan program asesmen tersebut, namun dalam penyususunan program asesmen ini akan lebih baik bila melibatkan ahli dan orang peserta didik guna untuk membuat program yang sesuai dengan perkembangan dan karakteristik anak. Dalam buku yang ditulis oleh masnipal (8) disebutkan bahwa dalam tahap perencanaan membuat / menyusun asesmen melibatkan peran penyelenggara, Lembaga pendidikan/sekolah, guru, orang tua, dan mungkin ahli terkait, seperti psikolog, konselor,dan dokter.

Instrumentyang digunakan untuk menilai perkembangan anak usia dini di di KB X Pangandaran adalah observasi, penugasan, hasil karya dan catatan anekdot. Instrumen ini sudah baik dan sesuai dengan karakteristik anak usia dini, namun akan lebih baik jika semua instrumen yang dianjurkan dan perlu digunakan guru dilakukan maka hasil asesmen akan jauh lebih baik karena setiap instrumen mempunyai kategori dan fungsinya masing-masing. Adapun instrumen atau teknik pengumpulan data yang bisa digunakan dalam melakukan penilaian terhadap perkembangan anak usia dini di KB X Pangandaran antara lain (9):

1. Observasi, yaitu kegiatan mengamati secara langsung tingkah laku dan aktivitas anak kapanpun dan dimanapun.

2. Percakapan, yaitu kegiatan yang dilakukan untuk mendaparkan data tentang pengetahuan, penalaran, pendapat, dan sikap anak tentang sesuatu.

3. Penugasan, yaitu kegiatan menugaskan anak mengerjakan suatu dalam

4. waktu yang sudah ditentukan, baik individu maupun kelompok.

5. Unjuk kerja, yaitu kegiatan mengajak anak untuk mengerjakan suatu aksi, seperti bernyanyi dan menyusun sepatu di rak.

6. Hasil karya, yaitu beraneka macam karya yang pernah dibuat oleh anak, seperti karya kolase dan menganyam.

7. Portofolio, yaitu kumpulan atau jejak rekam dari hasil kegiatan anak, termasuk catatan guru, foto kegiatan, rekaman suara anak, dan sebagainya.

8. Catatan anekdot, yaitu catatan kejadian insidentalanak seperti memukul teman atau menunjukan perilaku tertentu yang belum pernah terjadi sebelumnya.

Prisnip asemen yang harus dipegang guru KB X merupakan seluruh perinsip yang berada dalam pedoman kurikulum 2013 PAUD, dengan demikian guru KB X Pangandaran sudah memapu melaksanakan asesmen terhadap perkembangan anak usia dini sesuai dengan 
dengan prinsip asesmen yang dianjurkan. Adapun prinsip asesmen dalam pedoman penilaian kurikulum 2013 PAUD (8) adalah sebagai berikut :

1. Mendidik, maksudnya pendidik dapat memotivasi, membina anak dan menstimulus pertumbuhan serta perkembangan secara optimal dapat dilakuakuan dalam proses pelaksanaan dan bahkan hasil dari asesmen itu sendiri.

2. Berkesinambungan, maksdunya pelaksanaan asesmen harus dilakukan dengan terencana, bertahap, dan kontinu guna mendapatkan gambaran mengenai pertumbuhan dan perkembangan anak.

3. Objektif, maksudnya pelaksanaan asesmen terhadap perkembangan anak usia dini harus sesuai dengan fakta yang ada (yang sebenarnya)

4. Akuntabel, maksudnya pelaksanaan asesmen harus sesuai dengan prosedur dan kriteria yang jelas serta dapat dipertanggungjawabkan.

5. Transparan, maksudnya hasil asesmen dapat diakses oleh semua pihak yang bersangkutan dan orang tua.

6. Sistematis., maksunya pelaksanaan asesmen perlu disesuaikan dengan pertumbuhan dan perkembangan anak yang sedang berlangsung, pelaksanaan asesmen juga dilakukan secara terstruktur dan terprogram.

7. Menyeluruh, maksudnya dalam melaksanakan asesmen terhadap perkembangan anak usia dini harus melibatkan semau aspek pertumbuhan dan perkembangan anak. Asesmen dapat menyediakan kebutuhan anak termasuk anak berkebutuhan khusus.

8. Bermakna, maksudnya hasil asesmen diharapkan dapat memberikan data berupa informai mengenai perkembangan anak usia dini yang bermanfaat, baik untuk anak, orang tua, guru dan semua pihak yang terlibat.

Dalam melaksanakan asesmen terhadap perkembangan anak usia dini, KB X Pangandaran melaksanakan atau mencatat penilaia setiap hari setelah selesai pembelajaran di kelas melalui instrumen yang digunakan, namun hal ini tidak sesuai dengan pelaksanaan asesmen itu sendiri. Pada dasarnya asesmen terhadap perkembangan anak usia dini dilaksanakan ketika anak mulai datang atau masuk ke kelas sampai dengan anak pulang ke rumah atau selesai pembelajaran di sekolah, maka penilaian atau asesmen seharusnya dilakukan ketika anak mulai datang ke sekolah atau ke kelas, selama proses kegiatan pembelajaran berlangsung, bermain, melakukan hal-hal yang diinstruksikan oleh guru, sampai dengan anak pulang ke rumah sehingga hasil penilaian dapat lebih bermakna.

Menurut Eisele dari hasil penelitian yang dilakukan oleh Nurhanifah (10) mengemukakan bahwa asesmen /penilaian meliputi proses-proses berikut:

1. Asesmen penilaian harus berpusat pada anak dan pembelajaran di kelas

2. Asesmen penilaian dilakukan pada saat kegiatan berlangsung, alami dan merupakan penilaian dari kebiasan sehari - hari

3. Asesmen harus mendorong pada kekuatan/kelebihan anak, apa yang anak tahu, apa yang anak lakukan, dan bagaimana anak berkembanga sebagai pembelajar

4. Hal yang penting dalam melakukan asesmen adalah pengamatan guru. Mengamati bagaimana anak belajar dan berinteraksi dengan yang lainnya.

5. Mencakup Asesmen formal (tes terstandar, basal tes dan lain - lain), Asesmen informal (laporan anekdot, contoh anak dan lain - lain) dan masukan dari guru, anak dan orangtua

6. Mengumpulkan semua hasil kerja anak dalam portofolio. Hasilnya harus penuh arti dan otentik merefleksikan seluruh kemampuan anak.

Pendokumentasian hasil asesmen terhadap perkembangan anak usia dini di KB X Pangandaran sudah baik dilakukan, dimana pendokumentasian ini dilakukan berdasarkan kategori dari masing-masing penilaian. Dengan demikian, hasil asesmen di dokumentasikan dan disimpan dengan rapih sehingga akan mudah didapatkan atau ditemukan ketika diperlukan. Pengolahan data asesmen terhadap perkembangan anak usia dini di KB X sudah baik di lakukan yaitu dengan menerapkan empat tahap penilaian diantaranya; penilaian harian, penilaian mingguan, penilaian bulanan dan penilaian semesteran yang dilaksanakan dengan ceklis menggunakan skala perkembangan anak yaitu Belum Berkembang (BB), Mulai Berkembang (MB), Berkembangan Sesuai Harapan (MB), dan Berkembang Sangat Baik (BSB) sesuai 
dengan kompetensi dasar dan indikator capaian yang digunakan dari semua aspek perkembangan. Namun akan lebih baik bila dalam penilaian ini juga diterapkan peniliana triwulan atau penilaian yang dilakukan tiga bulan sekali guna untuk memberi kemudahan dan keefektifan pelaksanaan pengolahan data asesmen terhadap perkembangan anak usia dini. Selain itu, dalam melakukan pengolahan data, guru perlu memperhatikan langkah - langkah berikut (11):

1. Seluruh catatan skala perkembangan harian disatukan berdasarkan indikator dan Kompetensi Dasar yang sama.

2. Perhatikan status perkembangan anak dari berbagai instrumen penilaian harian. Dalam penilaian PAUD penilaian perkembangan anak dapat dilakukan menggunakan skala perkembangan, yaitu BB (Belum Berkembang), MB (Mulai Berkembang), BSH (Berkembang Sesuai Harapan), dan BSB (Berkembang Sangat Baik).

3. Penyimpulan status akhir perkembangan anak dari berbagai instrumen dan periode penilaian dapat dilakukan melalui dua cara yaitu mengambil capaian tertinggi pada setiap indikator atau kompensasi dasar yang sama dan mengambil rata-rata status perkembangan anak dari setiap indikator dan kompetensi dasar yang sama.

Asesmen terhadap perkembangan anak usia dini merupakan salah satu cara yang dapat dilakukan guru untuk membekali peserta didik dengan pembinaan PAUD harus diikuti. Penilaian dan pelaporan terhadap perkembangan anak usia dini (3) Asesmen terhadap perkembangan anak usia dini di KB X dilaporkan kepada orang tua dan sekolah dimana setiap pelaporan mempunyai waktunya masing-masing dan incidental. Pelaporan kepada orang tua dilakukan setiap hari melalui WhatApp grup guru dan orang tau peserta didik atau dilakukan secara langsung ketika bertemu di sekolah, pelaporan kepada orang tua juga dilakukan pada saat selesai pembelajaran di akhir semester melalui buku raport yang dikeluarkan oleh Dinas Pendidikan dan Kebudayaan Republik Indonesia. Pelaporan kepada sekolah dilakukan setiap hari dan diakhir semester sekaligus sebagai arsipan mengenai laporan selama satu semester. Selain kepada orang tua dan sekolah, hasil asesmen terhadap perkembangan anak usia dini juga dapat dilaporkan kepada Yayasan bahkan dinas terkait dengan bagaimana perkembangan peserta didik, bagaimana kemajuan dan apakah terdapat hambatan atau permasalahan yang dialami oleh anak atau peserta didik. Sehingga, bila terdapat hambatan atau permasalahan yang dialami oleh peserta didik pihak sekolah tidak hanya mendiskusikan dengan orang tua saja namun dapat melibatkan Yayasan, dinas, bahkan ahli untuk menangani permasalahan yang dialami oleh anak tersebut.

Asesmen terhadap perkembangan anak usia dini dilakukan untuk mendapatkan data berupa informasi atau gambaran secara jelas mengenai perkembangan anak. Tindak lanjut asesmen terhadap perkembangan anak usia dini di KB X antara lain:

1. Digunakan untuk mengevaluasi program pembelajaran

2. Digunakan sebagai bahan acuan dalam membuat / merencanakan program pembelajaran selanjutnya

3. Digunakan sebagai media komukasi orang tua dan guru

4. Digunakan untuk keperluan administratif

Hasil asesmen terhadap perkembangan anak usia dini di KB X Pangandaran dapat ditindak lanjuti dengan semestinya baik untuk keperluan peserta didik, sekolah, maupun orang tua namun agar hasil asesmen dapat lebih bermakna hasil asesmen ini juga dapat digunakan untuk kegiatan pembelajaran, mengdiagnostik perkembangan anak dan penelitian.

Menurut Decker dalam buku yang ditulis oleh Mansipal (8) mengemukakan bahwa "asesmen dapat digunakan sebagai salah satu faktor penempatan anak, baik dalam kelompok maupun program pembelajaran, untuk perencanaan kurikulum, artinya asesmen digunakan untuk menentukan kemajuan tujuan atau sasaran, alat berkomunikasi dengan orang tua, modifikasi kurikulum, menentukan metodologi, dan sebagai umpan balik belajar tuntas (master learning strategy) yang disebut asesmen formatif (formative assessment).

Selain itu, Hasil asesmen perkembangan anak usia dini dapat digunakan untuk (12)

1. Keperluan administratif, yaitu dapat digunakan sebagai laporan perkembangan anak usia 
dini, sebagai laporan tertulis kepada orang tua, dan untuk memberikan laporan secara berkala mengenai kemajuan Lembaga PAUD pada pihak yang bersangkutan

2. Kegiatan pembelajaran, yaitu dapat digunakan untuk merevisi dan meningkatkan pembelajaran serta mengenali perkembangan anak selama mengikuti kegiatan pembelajaran.

3. Kegiatan diagnostik, maksudnya hasil penilaian terhadap perkembangan anak usia dini dapat dipakai sebagai alat penentuan dalam mengarahkan dan menganalisis berbagai persoalan yang dihadapai anak

4. Penelitian, yaitu dapat digunakan sebagai bahan penelitian terkait asesmen perkembangan.

Faktor Pendukung dan Penghambat KB X Pangandaran dalam Melaksanakan Asesmen terhadap Perkembangan Anak Usia Dini

Pelaksanaan asesmen terhdap perkembangan anak usia dini tidak terlepas dari adanya faktor pendukung dan penghambat dari pelaksanaan asesmen itu sendiri. Adapun faktor pendukung dan penghambat KB Qalbun Sakir Pangandaran dalam melaksanakan asesmen baik bagi guru maupun bagi sekolah adalah sebagi berikut :

1. Faktor pendukung guru adalah adanya rasa tanggung jawab sebagai seorang pendidik anak usia dini untuk membantu terhadap perkembangan anak dan terjalinnya kerja sama tim yang baik (kompak) antar guru dalam melaksanakan asesmen terhadap perkembagan anak usia dini. sedangkan faktor penghambat guru dalam melaksanakan asesmen terhadap perkembangan anak usia dini adalah kurangnya pengetahuan dan pemahanan guru menganai asesmen terhadap perkembangan anak usia dini.

2. Faktor pendukung sekolah dalam adalah buku-buku tentang asesmen terhadap perkembangan anak usia dini, alat peraga edukatif (APE) dalam kegiatan pembelajaran, media pembelajaran, dan pengelola/kepala sekolah yang selalu mengingatkan untuk melakukan asesmen terhadap perkembangan anak usia dini. sedangkan faktor penghambat guru dalam melakukan asesmen adalah membutuhkan waktu yang tidak sedikit untuk melakukan pelaksanaan atau pencatatan asesmen terhadap perkembangan anak usia dini ini.

Berdasarkan hal tersebut maka untuk menangani faktor penghambat KB X Pangandaran baik untuk guru maupun sekolah, sekolah hendaknya memberikan pelatihan kepada guru tentang asesmen perkembangan anak usia dini yang bertujuan untuk meningkatkan pengetahuan, pemahaman serta keterampilan guru dalam melaksanakan asesmen terhadap perkembangan anak usia dini sehingga dapat meningkatkan layanan pendidikan sekolah yang lebih baik. Selain itu pengetahuan, pemahaman, dan keterampilan guru dalam melaksanakan asesmen terhadap perkembangan anak usia dini dapat meningkat dan hasil asesmen terhadap perkembangan anak usia dini dapat lebih bermakna.

\section{Kesimpulan}

\section{Analisis Pelaksanaan Asesmen terhadap Perkembangan Anak Usia Dini di KB X Pangandaran}

Berdasarkan pembahasan dalam penelitian ini, peneliti menyimpulkan beberapa hasil penelitian sebagai berikut:

1. Penyusunan program asesmen dilakukan berdasarkan hail evalusai dari asesmen sebelumny, kemudian dibuat dan atau diturunkan berdasarkan program Tahunan (PROTAH), Program Semesteran (PROSEM), Rencana Pelaksanaan Pembelajaran Mingguan (RPPM), dan Rencana Pelaksanaan Pembelajaran Harian (RPPH) Penyusunan program asesmen terhadap perkembangan anak usia dini di KB X Pangandaran dilakukan ketika akan memulai pembelajaran tahun ajaran baru secara bersama-sama di satu tempat yang dilakukan oleh pengelola/kepala sekolah dan semua guru kelompok (kelompok A dan kelompok B).

2. Instrumen atau teknik pengumpulan data yang digunakan untuk menilai perkembangan anak usia dini di KB X Pangandaran adalah; observasi, catatan anekdot, penugasan, dan hasil karya anak. 
3. Dalam pelaksanaan asesmen di KB X Pangandaran guru harus memegang seluruh prinsip-prinisp asesmen yang berada dalam pedoman Kurikulum 2013 PAUD antara lain; mendidik, berkesinambungan, objektif, akuntabel, transparan, sistematis, menyeluruh, dan bermakna.

4. Pelaksanaan asesmen terhadap perkembangan anak usia dini di KB X Pangandaran dilakukan setelah selesai pembelajaran di kelas. Pencatatan ini dilakukan setiap hari melalui observasi, catatan anekdot, penugasan, dan hasil karya anak yang dimasukan ke dalam penilaian harian

5. Pelaksanaan asesmen terhadap perkembangan anak usia dini yang diterapkan di KB X melalui empat tahap yaitu, penilaian harian, penilaian mingguan, penilaian bulanan, dan penilaian semesteran.

6. Pendokumentasian terhadap penilaian perkembangan anak usia dini di KB X dilakukan pada saat kegiatan pembelajaran dan disimpan atau diarsipkan berdasarkan kategori dari masing-masing penilaian.

7. Asesmen terhadap perkembangan anak usia dini di KB X dilaporkan kepada orang tua dan sekolah.

8. Tindak lanjut dari hasil asesmen terhadap perkembangan anak usia dini di KB X Pangandarana antara lain; digunakan untuk mengevaluasi program pembelajaran, digunakan sebagai bahan acuan dalam membuat /merencanakan program pembelajaran semester selanjutnya, digunakan sebagai bahan komunikasi antara guru dan orang tau peserta didik, dan digunakan untuk keperluan administratif.

Faktor Pendukung dan Penghambat KB X Pangandaran dalam Melaksanakan Asesmen terhadap Perkembangan Anak Usia Dini

1. Faktor pendukung bagi guru adalah Adanya rasa tanggung jawab pada guru terhadap kewajiban sebagai seorang pendidik anak usia dini untuk membantu terhadap perkembangan anak dan terjalinnya Kerja sama tim yang baik (kompak) di KB X dalam melakukan asesmen perkembangan anak usia dini, mulai dari perencanaan sampai dengan evaluasi. Sedangkan faktor penghambat bagi guru adalah kurangnya pengetahuan dan pemahaman guru tentang asesmen perkembangan anak usia dini, salah satunya pada teknik pengumpulan data terhadap asesmen perkembangan anak usia dini.

2. Bagi sekolah faktor pendukungnya adalah buku-buku mengenai asesmen perkembangan anak usia dini, alat peraga edukatif (APE) dalam kegiatan pembelajaran, media pembelajaran, dan pengelola/kepala sekolah yang selalu mengingatkan untuk melakukan asesmen terhadap perkembangan anak usia dini. sedangkan faktor penghambatnya adalah pelaksanaan asesmen terhadap perkembangan anak usia dini yang membutuhkan cukup banyak waktu.

\section{Acknowledge}

Dalam penulisan artikel ini, penulis mengucapkan terimakasih yang sebesar-besarnya kepada pihak-pihak yang telah membantu, memotivasi, dan mendorong penulis sehingga penulis dapat menyelesaikannya artikel ini dengan baik :

1. Kedua orang tua penulis yang penulis cintai dan sayangi, bapak R. Deden Pusaka Drajat (alm) dan Ibu Eep Setiawati yang selalu memberikan doa dan dukungan kepada penulis sehingga penulis dapat menyelesaikan skripsi ini

2. Saudara saya (Kakak dan adik), Diana Jesicha Rahmawaty, Denty Arya Dewi, Edi Suryadi, R. Deri Pusaka Drajat, Desi Saraswaty, R. Dasep Pusaka Drajat, R. Dendi Pusaka Drajat, dan Muhammad Rahman yang selalu memberikan motivasi, dukungan dan doa kepada penulis Prof. Dr. H. Edi Setiadi, S.H., M.H. selaku rektor Universitas Islam Bandung

3. Enoh, Drs., M.Ag. selaku dekan Fakultas Tarbiyah dan Keguruan atas dedikasinya terhadap Fakultas Tarbiyah dan Keguruan Universitas Islam Bandung

4. Dr. Erhamwilda, Dra., M.Pd. selaku Ketua Program Studi Pendidikan Guru Pendidikan Anak Usia Dini Universitas Islam Bandung

5. Dr. Masnipal, M.Pd. selaku dosen pembimbing I yang telah membimbing, memberikan 
motivasi dan dukungan kepada penulis dari awal revisian hasil ujian proposal penelitian hingga selesainya penelitian yang dilakukan oleh penulis.

6. Dr. Helmi Aziz, M.Pd.I. selaku dosen pembimbing II yang telah membimbing dan memberi dukungan kepada penulis sehingga penulis dapat menyelesaikan skripsi ini dengan baik

7. Seluruh dosen Program Studi Pendidikan Guru Pendidikan Anak Usia Dini yang telah memberikan ilmunya yang sangat bermanfaat bagi penulis. Semoga Allah SWT meridhoi dan memberikan balasan yang baik atas semua ilmu yang telah diberikan.

8. Dini Anisa, S.Pd,I, selaku kepala sekolah KB X Pangandaran yang telah mengizinkan penulis untuk melaksanakan penelitian deskriptif kualitatif. Semoga menjadi amal shalih yang tiada putus.

9. Lulu Dwi Hayati selaku guru KB X Pangandaran yang sudah berkenan membantu dan memberikan pengalamannya. Semoga Allah SWT membalas semua kebaikannya.

10. Sahabat dunia akhirat penulis yang selalu menguatkan dan memberikan motivasi dikala jenuh dan malas melanda. Kepada sahabat penulis yang penulis sayangi Lisna Maulina Nur'Asyah, Nur Ega Rizky, Qatrunnada Mufidah dan

11. Nur Husna Hasibuan. Juga sahabat perjuangan kuliah penulis di Kampus Unisba yakni Nurhamida, Alisan Ridha Musthafa, Devita Nurul Fatimah dan Febby Elinda. Tak lupa kepada seluruh mahasiswa Angkatan Generation of Chage 2018 Program Studi Pendidikan Guru Pendidikan Anak Usia Dini yang telah menemani penulis dalam tiga setengah tahun terakhir. Semoga Alloh SWT, membalas kebaikan teman-teman semuanya.

12. Pihak-pihak yang tidak penulis sebutkan satu persatu. Penulis sampaikan Jazakumullah Khairan Katsiran telah membantu dan memberikan doa kepada penulis dalam proses penulisan skripsian ini hingga selesai.

Akhirnya, penulis hanya dapat memanjatkan do'a kepada Alloh SWT semoga segala dukungan, doa, motivasi, dan bantuannya dibalas oleh Alloh SWT. Aamiin Ya Rabbal Alamin.

\section{Daftar Pustaka}

[1] Masnipal. Menjadi Guru PAUD Profesional. Kholid A, editor. Bandung: PT Remaja Rosdakarya; 2018. 2-234 p.

[2] Arumsari AD, Putri VM. Asesmen Perkembangan Anak Usia Dini. Motoric. 2020;4(1):15460.

[3] Wortham SC, Hardin BJ, Kevin P, Clark S. Asesmen dalam Pendidikan Anak Usia Dini. Kevin Davis. 2020.

[4] Maryani K. Penilaian dan Pelaporan Perkembangan Anak Saat Pembelajaran di Rumah di Masa Pendemi Covid-19. Murhum J Pendidik Anak Usia Dini. 2020;1(2):41-52.

[5] Ummah MZ. Implementasi Asesmen Perkembangan Anak Usia Dini Di Tk Islam Kanita Tiara Baki Sukoharjo Tahun Ajaran 2018-2019. 2020.

[6] K OP, T RS, Patience FO. Jurnal Pendidikan Anak Usia Dini Indonesia Perceived Training Needs of Teachers in Early Childhood Assessment: Pathway to Achieving Target 2 of Sustainable Development Goal 4 di Nigeria. 2019;8(1).

[7] Sardiarinto S, Sulistyo GB, Safitri LA, Kiswati S. Aplikasi Sistem Penilaian Perkembangan Anak Pada Pos Paud Abimanyu. Bianglala Inform. 2020;8(2):111.

[8] Hapidin. Pembelajaran 6. Asesmen Perkembangan Anak Usia Dini. Modul Belajar Mandiri. 2019;127-32.

[9] Masnipal. Siap Menjadi Guru dan Pengelola PAUD Profesional (Pijakan Mahasiswa, Guru, dan Pengelola TK/RA/KB/TPA). Jakarta: PT Gramedia; 2013. 186 p.

[10] Nurhanifah. Teknik Dan Instrumen Penilaian Perkembangan Bahasa Anak Usia 4-5 Tahun Di TK Hang Tuah Kotabumi Lampung Utara. Journal of Visual Languages \& Computing. 2019. 17-18 p.

[11] Jaya PRP. Pengolahan Hasil Penilaian Pendidikan Anak Usia Dini. J Lonto Leok Pendidik Anak Usia DIini. 2019;2(1):80-2. 
[12] Aini AN. Implementasi Asesmen Perkembangan Anak Usia Dini di TK Pembina Traji Kecamatan Parakan Kabupaten Temanggung. 2017. 